\title{
STUDI KINETIKA EKSTRAK JAMBU BIJI TERHADAP PENYEMBUHAN DEMAM BERDARAH
}

\author{
Crismonia rinta*1 \\ ${ }^{1}$ Jurusan kimia, FMIPA, Universitas Negeri Padang Indonesia \\ *E-mail: crismoniarinta.cr7@gmail.com
}

\begin{abstract}
Abstrak. Studi ini bertujuan untuk membuat ekstrak buah jambu biji merah untuk membantu proses penyembuhan demam berdarah. Metode yang dilakukan adalah eksperimen dan uji akrivitas katalitik secara langsung. Uji aktifitas langsung dilakukan dengan variasi dua kali minum selama satu hari sebanyak satu gelas. Hasil eksperimen membuktikan bahwa ekstrak buah jambu biji merah dapat membantu proses penyembuhan demam berdarah. Kondisi optimum ekstrak buah jambu biji merah tercapai pada dua hari konsumsi ekstrak sebanyak empat gelas. Penyembuhan ini diduga karena aktivitas katalitik ekstrak buah jambu biji merah terhadap pembentukan trombosit darah.
\end{abstract}

Kata kunci : jambu biji merah, katalitik, trombosit

\section{PENDAHULUAN}

[1]Reaksi kimia merupakan suatu proses yang sangat penting bagi kehidupan. Suatu reaksi kimia akan menghasilkan suatu perubahan dengan munculnya suatu zat baru yang mempunyai sifat yang berbeda dengan pereaksi.[2]Reaksi kimia dipercepat dengan adanya katalis.[3] Aktifitas katalis akan mempercepat terbentuknya suatu produk dalam suatu reaksi. Reaksi kimia dapat terjadi dalam berbagai hal termasuk dalam tubuh manusia juga terjadi suatu reaksi kimia. Berbagai proses kimia dan aktifitas sel juga melibatkan[4] reaksi kimia dalam tubuh manusia.

[5]Katalis yang berfungsi sebagai faktor yang mempercepat terjadinya suatu reaksi ada yang berasal dari bahan kimia dan adanya yang berasal dari bahan alam [6] seperti tumbuhan. Beberapa dari tumbuhan dapat dimanfaatkan sebagai katalis atau berfungsi sebagai katalis. [7] Dimana katalis yang berasal dari tumbuhan dapat membantu proses penyembuhan 
penyakit. Proses penyembuhan dapat terjadi karena adanya aktifitas katalitik. [8] Katalis tidak hanya membantu proses penyembuhan suatu penyakit, katalis juga dapat berfungsi sebagai antioksidan dan meningkatkan sistem kekebalan tubuh. Salah satu katalis yang berasal dari bahan alam adalah jambu biji.

Jambu biji merupakan tumbuhan yang banyak ditemui di indonesia. Untuk pengolahan nya pun sangat mudah dilakukan dan bisa langsung dikonsumsi [9]. Jambu biji merah mempuyai rasa yang manis sehingga banyak dikonsumsi dengan mengolahnya menjadi jus.Dalam buah jambu biji mengandung vitamin $\mathrm{C}$ yang dapat membantu proses pembentukan trombosit darah. [10] Kandungan vitamin $\mathrm{C}$ dalam jambu biji merah merupakan kadar paling tinggi dibandingkan dengan buah-buahan yang lain.[11] Selain itu buah jambu biji merah juga mengandung kalsium dan mineral yang juga berfungsi sebagai pendukung dalam proses pembentukan trombosit darah. Salah satu manfaat dari konsumsi jambu biji merah ini adalah dapat membantu proses penyembuhan penyakit demam berdarah.

[12] Demam berdarah merupakan [13] suatu penyakit yang disebabkan oleh virus dengue yang ditularkan melalui gigitan nyamuk aedes aegypti. Gejala demam berdarah awalnya ditandai dengan demam yang tinggi serta kondisi tubuh yang lemah selama 2-7 hari. [14] Penyakit demam berdarah tergolong penyakit yang bisa menular. Sehingga diperlukan pencegahan serta pengobatan yang tepat. Salah satunya dengan pemanfaatan buah jambu biji merah. Dimana buah jambu biji merah bisa digunakan sebagai obat [15] dalam penyembuhan demam berdarah.

[16]Demam berdarah dapat dihindari dengan meningkatkan sistem kekebalan tubuh serta mengkonsumsi makanan yang mengandung antioksidan yang tinggi.[17][18] Selain itu juga harus menjaga kondisi lingkungan yang bersih sehingga terbebas dari virus yang menyebabkan demam berdarah.[19][20]Untuk meningkatkan daya tahan tubuh dapat 
dilakukan dengan mengkonsumsi ekstrak buah jambu biji merah yang mengandung kadar antioksidan serta vitamin $\mathrm{C}$ yang tinggi.

[21]Berdasarkan informasi yang diperoleh mengenai ekstrak buah jambu biji merah yang dipercaya mampu membantu proses penyembuhan demam berdarah. Peneliti tertarik untuk melakukan melakukan pengujian mengenai pengaruh ekstrak buah jambu biji terhadap penyembuhan demam berdarah. Penelitian ini bertujuan untuk membuktikan [22] apakah ekstrak buah jambu biji merah dapat menyembuhkan penderita demam berdarah.

\section{METODE PENELITIAN}

\subsection{Alat dan Bahan}

Peralatan dan bahan yang digunakan dalam penelitian studi kinetika ekstrak buah jambu biji merah terhadap penyembuhan demam berdarah adalah

a. Alat

- Gelas (kode KIG)

- Pisau (kode XYJ)

- Blender (Miyako)

- $\quad$ Kamera (Samsung Galxy J3 Pro)

b. Bahan

- Buah jambu biji merah

- $\quad$ Air (Aqua).

\subsection{Pembuatan Ekstrak}

Prosedur kerja dari studi ini adalah : menyiapkan satu buah jambu biji merah kemudian dicuci dengan bersih. Buah jambu biji dipotong menjadi beberapa bagian. Buah yang telah dipotong diekstrak menggunakan blender dengan penambahan $100 \mathrm{~mL}$ air. Ekstrak 
dimasukkan kedalam gelas dan siap untuk diujikan. Satu gelas ekstrak buah jambu biji diberikan kepada pasien demam berdarah. Selanjutnya meminta keterangan kepada pasien demam berdarah setelah satu hari.

Metode ini dapat dibuat secara diagram alir :

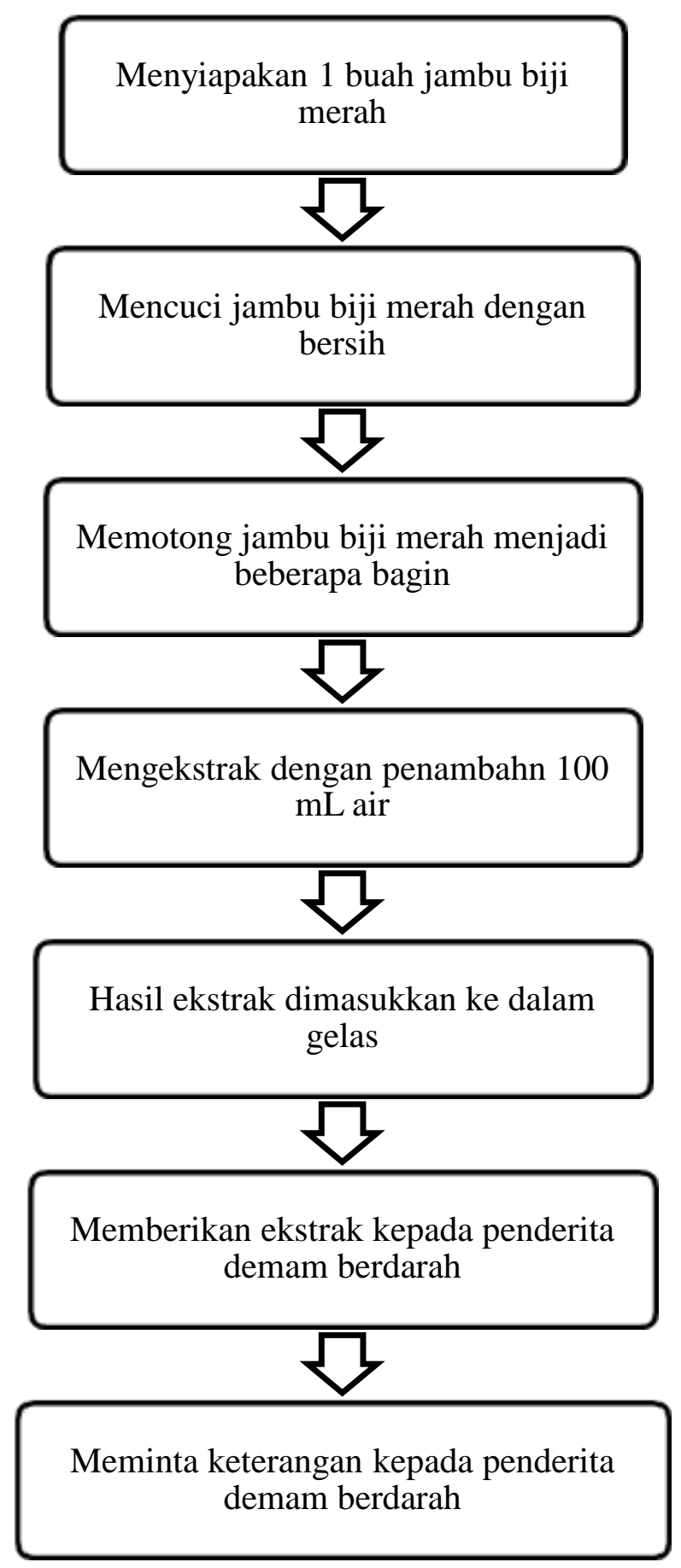




\section{Hasil}

\subsection{Hasil Pembuatan}

Hasil pembuatan ekstrak buah jambu biji merah sebanyak 1 buah dengan $100 \mathrm{~mL}$ air. Hal ini dapat dilihat pada gambar di bawah ini :

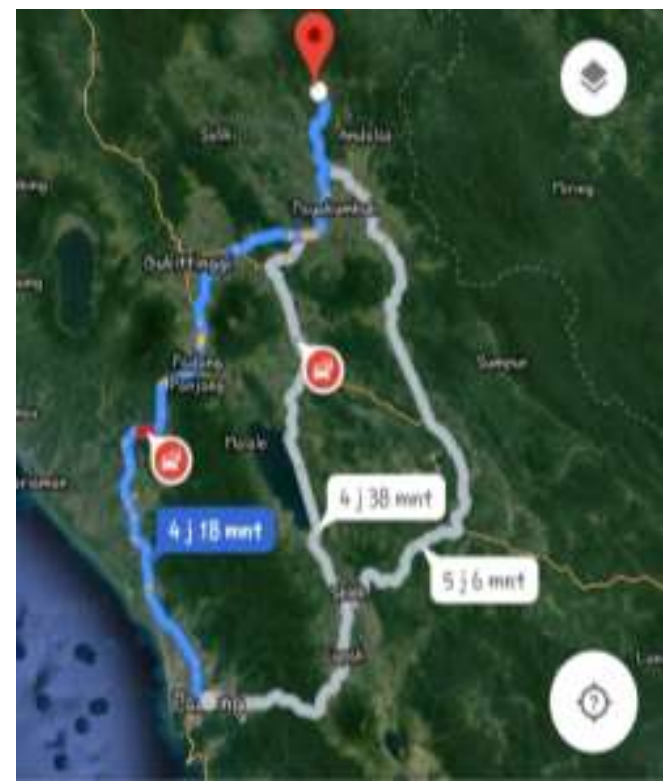

Daerah pengambilan sampel di Kenagarian Sungai Antuan, Kec. Mungka, Kab. Lima Puluh Kota

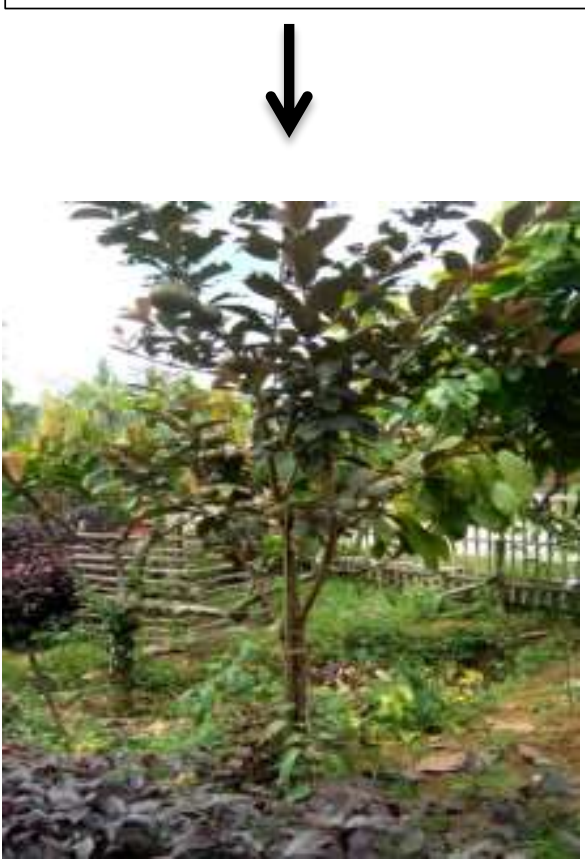



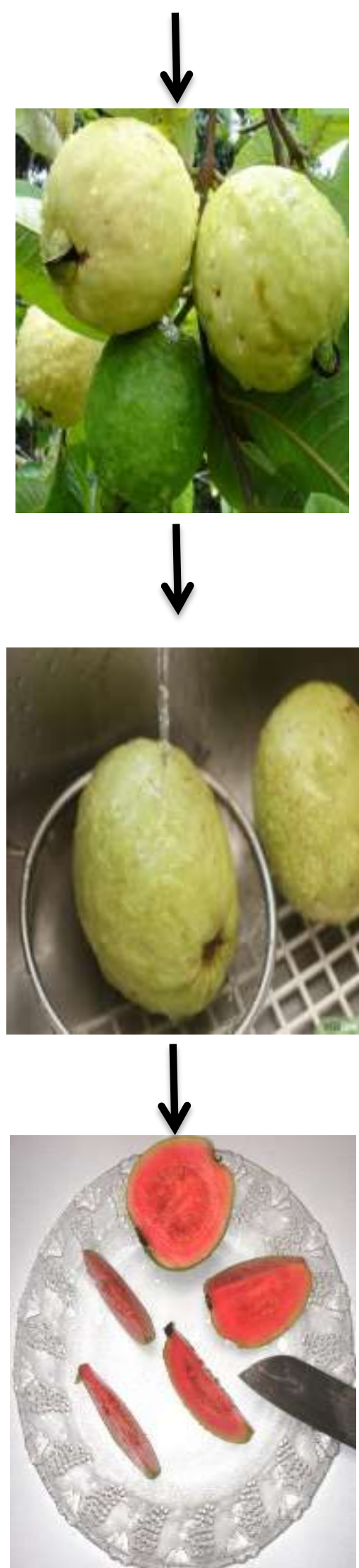

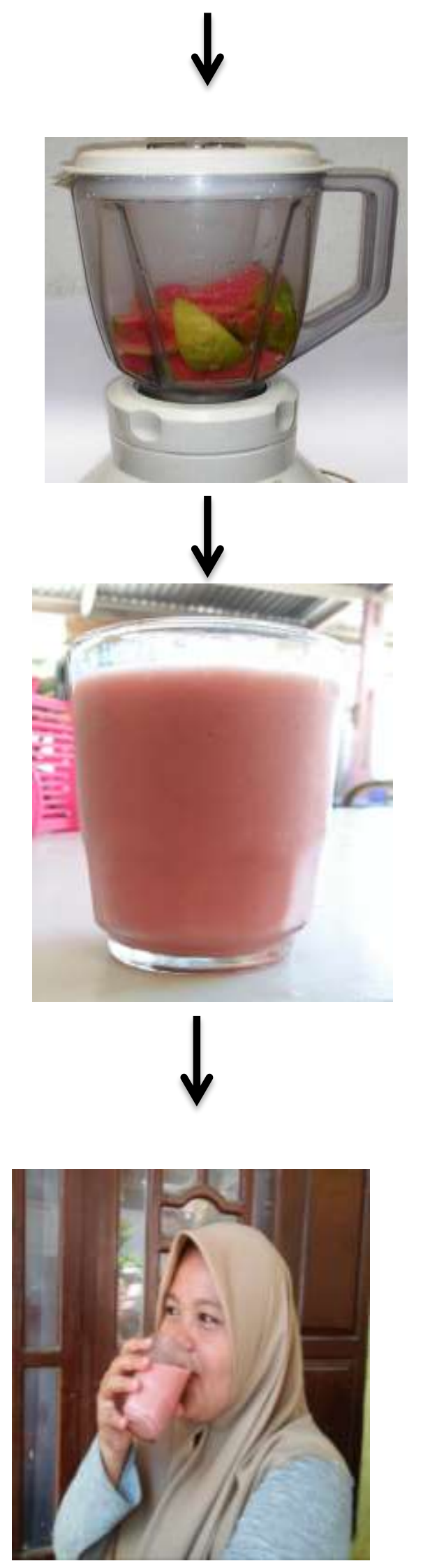


\subsection{Hasil Uji Coba}

Pengujian terhadap penderita demam berdarah ternyata berhasil menyembuhkan penderita demam berdarah sebagaimana dapat dilihat pada tabel berikut :

Tabel 1 : Hasil Uji Coba Ekstrak Buah Jambu Biji Merah

\begin{tabular}{|c|c|c|}
\hline baHari & Jumlah konsumsi ekstrak & Kadar trombosit $\left(/ \mathrm{cm}^{3}\right)$ \\
\hline 1 & 2 gelas & $30000 / \mathrm{cm}^{3}$ \\
\hline 2 & 2 gelas & $60000 / \mathrm{cm}^{3}$ \\
\hline 3 & 2 gelas & $90000 / \mathrm{cm}^{3}$ \\
\hline 4 & 2 gelas & $120.000 / \mathrm{cm}^{3}$ \\
\hline
\end{tabular}

\section{PEMBAHASAN}

\subsection{Pembuatan}

[23]Tumbuhan jambu biji merupakan tumbuhan yang banyak tersebar di seluruh indonesia.[24] Untuk memperoleh buah yang sudah matang untuk di ekstrak sedikit sulit ditemukan karena jambu biji tidak selalu berbuah setiap waktu melainkan dalam jangka waktu tertentu. Dalam mengkonsumsi buah jambu biji merah ini sangat mudah dilakukan, buah nya bisa dikonsumsi secara langsung dan bisa diolah menjadi jus buah.

[25]Dalam pengolahan buah jambu biji harus benar-benar diperhatikan kebersihan buah.Buah jambu biji bisa diolah menjadi jus dengan cara memotong buah jambu biji menjadi bagian-bagian yang lebih kecil. Potongan dari buah jambu biji di blender hingga halus dengan penambahan beberapa $\mathrm{mL}$ air. Setelah itu jus buah jambu biji bisa dikonsumsi secara langsung. 


\subsection{Uji Coba}

[26] Untuk mengatasi kekurangan kadar trombosit dalam darah dapat dilakukan dengan mengkonsumsi buah yang kaya akan vitamin dan nutrisi. Salah satunya dengan mengkonsumsi ekstrak buah jambu biji . Dari penelitian yang dilakukan diperoleh data :

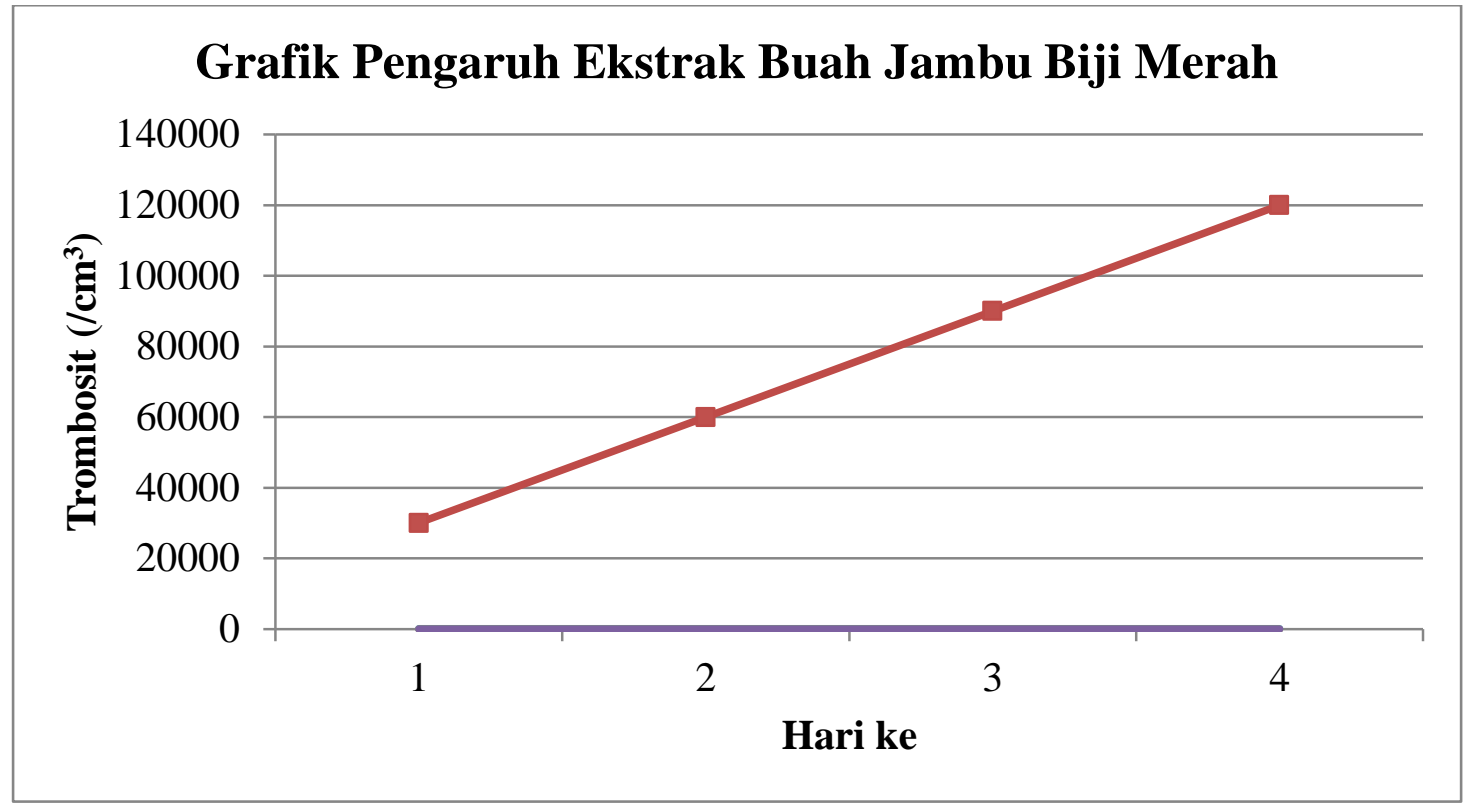

Gambar 1 : Grafik Pengaruh Ekstrak Buah Jambu Biji Merah

[27] Dari grafik terlihat peningkatan kadar trombosit darah selama empat hari konsumsi ekstrak buah jambu biji merah.[28] Semakin banyak konsumsi ekstrak jambu maka kadar trombosit darah semakin tinggi.Hal tersebut dapat terjadi karena dalam buah jambu biji merah mengandung vitamin $\mathrm{C}, \beta$ karoten, vitamin B1,B2 dan B6. Buah jambu biji merah mengandung kadar vitamin $\mathrm{C}$ yang sangat tinggi yaitu dalam 100 gram buah jambu biji mengandung $100 \mathrm{mg}$ vitamin $\mathrm{C}$.

\subsection{Interaksi}

[29][30]Buah jambu biji merah mengandung senyawa quarcetin yang tergolong senyawa flavonoid serta sitokin yang berfungsi meningkatkan kekenyalan pembuluh darah sekaligus berperan[31] dalam meningkatkan sistem pembekuan darah. Selain itu buah jambu 
biji merah juga berfungsi untuk memperbaiki kapiler darah sehingga tidak terjadi kebocoran. Oleh karena itu pecahnya pembuluh darah dapat dicegah dengan mengkonsumsi buah jambu biji merah secara rutin. Buah jambu biji merah juga mengandung likopen yang berfungsi sebagai antioksidan dalam tubuh. Buah jambu biji juga dapat mencegah berkembangnya virus penyebab demam berdarah.

[32]Jika pasien demam berdarah mengkonsumsi buah jambu biji ini secara rutin (2 gelas ekstrak buah jambu biji per hari), maka akan meningkatkan produksi trombosit dalam darah. Sehingga pertumbuhan virus dalam tubuh penderita dapat terhambat.[33] Dalam dua hari konsumsi buah jambu biji akan terlihat perubahan yang signifikan dari penderita.

Disini dapat terlihat peran buah jambu biji sebagai suatu katalis yang berasal dari bahan alam. Hal tersebut dapat diamati dengan adanya proses katalitik dari buah jambu biji merah yang dapat membantu proses penyembuhan pasien demam berdarah.[34] Proses tersebut dapat berlangsung karena adanya reaksi [35] antara senyawa yang dikandung oleh buah jambu biji merah dengan trombosit darah.

\section{KESIMPULAN}

1) Ekstrak buah jambu biji merah dapat dibuat dari 250 gram buah jambu biji dengan 100 $\mathrm{mL}$ air yang menghasilkan satu gelas ekstrak buah jambu biji merah

2) Ekstrak buah jambu biji ini dapat menyembuhkan penyakit demam berdarah setelah komsumsi ekstrak selama empat hari berturut-turut.

3) Ekstrak buah jambu biji dapat menyembuhkan penyakit demam berdarah karena mengandung senyawa quarcentin yang tergolong flavonoid, sitokin yang berfungsi dalam pembekuan darah serta vitamin $\mathrm{C}$, vitamin $\mathrm{B} 1$, B2 dan $\mathrm{B} 6$ yang berperan sebagai antioksidan untuk menjaga sistem kekebalan tubuh terhadap infeksi virus dengue. 


\section{REFERENSI}

[1] Amananti, W. (2017) "Analisis Mikrostruktur Lapisan Tipis Tio2:Zno Yang Dideposisikan Diatas Subtrat Kaca Dengan Metode Spray Coating Untuk Degradasi Limbah Zat Warna", EKSAKTA: Berkala Ilmiah Bidang MIPA, 18(02), pp. 210-215. doi: 10.24036/eksakta/vol18-iss02/81.

[2] Sanjaya, H. (2018) "Degradasi Metil Violet Menggunakan Katalis Zno-Tio2 Secara Fotosonolisis", EKSAKTA: Berkala Ilmiah Bidang MIPA, 19(1), pp. 91-99. doi: 10.24036/eksakta/vol19-iss1/131.

[3] Hartiniati,Hartiniati.2008. Evaluasi Reaktifitas Katalis Nimo Dalam Proses Pencairan Batubara Banko Selatan Dan Australian Loy Yang. Jurnal Energi Dan Lingkungan (Enerlink). Vol.4 No. 1

[4] Shafitri, M., \& Zainul, R. (2019, February 3). Vanadium Pentaoksida (V2O5) : Termodinamika Molecular dan Interaksi Ion dalam Larutan. https://doi.org/10.31227/osf.io/jgmvd

[5] Prabowo, H. (2018) "Penyelidikan Kelayakan Kimia Dan Penyebaran Cadangan Pasir Besi Daerah Tiku Kabupaten Agam Untuk Bahan Baku Semen Pada Pt. Semen Padang”, EKSAKTA: Berkala Ilmiah Bidang MIPA, 19(1), pp. 39-42. doi: 10.24036/eksakta/vol19-iss1/121.

[6] Husna, H., \& Zainul, R. (2019, February 3). A Review : Aspek Termodinamika LiNO3 dalam Larutannya. https://doi.org/10.31227/osf.io/45mbd

[7] Firdausy, Kartika, Yudhana, Anton, Sugianto, Ikhsan. 2006. Visualisasi Metode Refleksologi Untuk Penyembuhan Penyakit Dengan Visual Basic. Vol.4 No.1 
[8] Shafitri, M., \& Zainul, R. (2019, February 3). Vanadium Pentaoksida (V2O5) : Termodinamika Molecular dan Interaksi Ion dalam Larutan. https://doi.org/10.31227/osf.io/jgmvd

[9] Wiralis, Wiralis, Purwaningsih, Endang. 2009. Pengaruh Pemberian Jus Jambu Biji (Psidium Guajava L) Terhadap Volume Kaki dan Kadar Ion Nitrit Adjuvant Induced Arthritis Tikus Wistar. Vol. 43 No.4

[10] Rukmiasih, PS, Hardjosworo, PP, Kataren, PR, Matitaputty. 2010. Penggunaan beluntas, vitamin $C$ dan E sebagai antioksidan untuk menurunkan off-odor (25\%) daging itik alabio dan Citaheup. Jurnal Ilmu Pertanian Indonesia. Vol.15 No.2

[11] Setianto, S. (2017) “Analisa Kuantitatif Campuran Senyawa Oksida Sebagai Dasar Identifikasi Kandungan Bahan Sumber Daya Alam Studi Kasus : Kandungan Mineral Pada Pasir Besi Di Pesisir Pantai Selatan, Jawa Barat”, EKSAKTA: Berkala Ilmiah Bidang MIPA, 18(02), pp. 173-177. doi: 10.24036/eksakta/vol18-iss02/74.

[12] Upik Kesumawati Hadi, Susi Soviana, Dwi Djayanti Gunandini. 2012. Aktivitas nokturnal vektor demam berdarah dengue di beberapa daerah di Indonesia. Jurnal Entomologi Indonesia. Vol.9 No.1

[13] Lubis, A. P., \& Zainul, R. (2018, November 5). Interaksi Molekuler Amonium Hidroksida. https://doi.org/10.31227/osf.io/jht3b

[14] Susilaningrum, D. (2017) "Pemodelan Regresi Logistik Pada Faktor Yang Mempengaruhi Phbs Pada Rumah Tangga Penderita Tbc Di Pesisir Surabaya”, EKSAKTA: Berkala Ilmiah Bidang MIPA, 18(02), pp. 121-128. doi: 10.24036/eksakta/vol18-iss02/65.

[15] Feronika, N. I., \& Zainul, R. (2018, November 19). Kalium Permanganat: Termodinamika Mengenai Transport Ionik dalam Air. https://doi.org/10.31227/osf.io/g6eyk 
[16] Damayanthi, Evy, Kustiyah, Lilik, Khalid, Mahani, Farizal, Henry.2010. Aktivitas Antioksidan Bekatul Lebih Tinggi Daripada Jus Tomat Dan Penurunan Aktivitas Antioksidan Serum Setelah Intervensi Minuman Kaya Antioksidan. Jurnal gizi dan pangan. Vol.5 No.3

[17] Hartawan, Risza,Dharmayanti, Ni Luh Putu Indi, Robinson, Karl, Mahony, Timothy, Meers,Joanne. 2012. Expression Of Two N1 Clones With Single Amino Acid Dissimilarity Of Avian Influenza H5n1 Virus. Hayati Journal Of Biosciences. Vol.19 No.4

[18] Horiza, H., Azhar, M. and Efendi, J. (2017) “Ekstraksi Dan Karakterisasi Inulin Dari Umbi Dahlia (Dahlia Sp.L) Segar Dan Disimpan”, EKSAKTA: Berkala Ilmiah Bidang MIPA, 18(01), pp. 31-39. doi: 10.24036/eksakta/vol18-iss01/14.

[19] Gunawan Giu, La Ode Muh., Ramli, Muhammad, Alirman Afu, La Ode. 2017. Perbandingan Daya Tahan Tubuh Ikan Ternate Chromis (Chromis Ternatensis) Dan Common Goby (Bathygobius Fuscus) Terhadap Kenaikan Suhu Pada Wadah Terkontrol. Jurnal Sapa Laut (Jurnal Ilmu Kelautan). Vol.2 No.1

[20] Sari, A. (2017) "Potensi Antioksidan Alami Pada Ekstrak Daun Jamblang (Syzigium Cumini (L.) Skeels)”, EKSAKTA: Berkala Ilmiah Bidang MIPA, 18(02), pp. 107-112. doi: 10.24036/eksakta/vol18-iss02/61.

[21] Hidayani, T. (2018) "Grafting Polipropilena Dengan Maleat Anhidrida Sebagai Pengikat Silang Dengan Inisiator Benzoil Peroksida", EKSAKTA: Berkala Ilmiah Bidang MIPA, 19(1), pp. 56-62. doi: 10.24036/eksakta/vol19-iss1/127.

[22] Zainul, R., Effendi, J., \& M. (2018, December 10). Phototransformation of Linear Alkylbenzene Sulphonate (LAS) Surfactant Using ZnO-CuO Composite Photocatalyst. https://doi.org/10.31227/osf.io/fec28

[23] Kristy, D. P., \& Zainul, R. (2019, February 3). Analisis Molekular dan Transpor Ion Natrium Silikat. https://doi.org/10.31227/osf.io/8ac4m 
[24] Rizki Saputra, M. and Sumarmin, R. (2018) "Pengaruh Ekstrak Daun Sirih Merah (Piper Crocatum Ruiz \& Pav.) Terhadap Glukosa Darah Mencit (Mus Musculus L.) Jantan Yang Diinduksi Sukrosa", EKSAKTA: Berkala Ilmiah Bidang MIPA, 19(1), pp. 43-55. doi: 10.24036/eksakta/vol19-iss1/124.

[25] Sarjani, F., Sri Sumantyo, J. T. and Yohandri, Y. (2017) "Pengolahan Citra Satelit Alos Palsar Menggunakan Metode Polarimetri Untuk Klasifikasi Lahan Wilayah Kota Padang”, EKSAKTA: Berkala Ilmiah Bidang MIPA, 18(01), pp. 69-77. doi: 10.24036/eksakta/vol18-iss01/21.

[26] Amurwaningsih, Musri, Arum Darjono, Uswatun Nisa. 2010. Analisis Hubungan Kualitas Hidup Yang Berhubungan Dengan Kesehatan Mulut (OHRQoL) Dan Status Kecemasan Dengan Status Nutrisi Pada Masyarakat Usia Lanjut. Majalah Ilmiah Sultan Agung. Vol.48 No.123

[27] Effendi, Adi Teruna, Sediono, M, Suksmono, HS, Erwanto, B, Effendi, Yekti Hartati, Dewi, Mira, Karyadi, Darwin. 2010. Efektivitas Pemberian Cgf 40\% Dalam Mempercepat Peningkatan Trombosit Pada Penderita Demam Berdarah Dengue. Jurnal Gizi dan Pangan. Vol.5 No.3

[28] Putri, D. F., Ritonga, H. M., Murdiati, V., \& Zainul, R. (2018, October 15). A Review What Is Hydrothermal ?. https://doi.org/10.31227/osf.io/dm56c

[29] Dinata, M. and Soehardi, F. (2018) "Factor Analysis Of Physics Chemistry Waters That Affects Damage Safety Cliff On The Outskirts Of River Siak”, EKSAKTA: Berkala Ilmiah Bidang MIPA, 19(2), pp. 46-49. doi: 10.24036/eksakta/vol19-iss2/143.

[30] Parbuntari, H., Prestica, Y., Gunawan, R., Nurman, M. and Adella, F. (2018) "Preliminary Phytochemical Screening (Qualitative Analysis) of Cacao Leaves (Theobroma cacao L.)”, EKSAKTA: Berkala Ilmiah Bidang MIPA, 19(2), pp. 40-45. doi: 10.24036/eksakta/vol19-iss2/142.

[31] Zainul, R. (2018, August 16). Determination of the half-life and the quantum yield of $\mathrm{ZnO}$ semiconductor photocatalyst in humic acid. https://doi.org/10.31227/osf.io/e8a9x 
[32] Syafei, N. (2017) “Analisa Fenomena Korosi Pelat Pipa Baja Karbon Api 5l-X65 Dalam Larutan $250 \mathrm{Ml}$ Asam Asetat Dan 4750 Ml Aquades Pada Kondisi Gas Co2 Dan H2s Jenuh Pada Suhu Ruang”, EKSAKTA: Berkala Ilmiah Bidang MIPA, 18(02), pp. 113-120. doi: 10.24036/eksakta/vol18-iss02/63.

[33] Prihatini, R. (2017) "PEMANFAATAN AIR KELAPA UNTUK MENINGKATKAN PERTUMBUHAN AKAR STEK TUNAS AKSILAR Andrographis Paniculata Nees", EKSAKTA: Berkala Ilmiah Bidang MIPA, 18(02), pp. 62-68. doi: 10.24036/eksakta/vol18-iss02/54

[34] Yanuar, F., Tillah, M. and Devianto, D. (2018) “Modeling of Human Development Index Using Ridge Regression Method", EKSAKTA: Berkala Ilmiah Bidang MIPA, 19(2), pp. 1-11. doi: 10.24036/eksakta/vol19-iss2/134.

[35] Febriani, S. S., Yolanda, T., Arianti, V. A., \& Zainul, R. (2018, October 12). A Review Solid Stated : Principles and Methode. https://doi.org/10.31227/osf.io/7us4x 